\title{
Pseudanabaena foetida sp. nov. and P. subfoetida sp. nov. (Cyanophyta/ Cya- nobacteria) producing 2-methylisoborneol from Japan
}

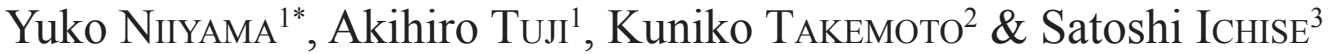 \\ ${ }^{1}$ Department of Botany, National Museum of Nature and Science, 4-1-1 Amakubo, Tsukuba, Ibaraki 305- \\ 0005, Japan;*Corresponding author e-mail: 3ken@kahaku.go.jp \\ ${ }^{2}$ Department of physics, Kansai Medical University, 2-5-1 Shin-machi, Hirakata, Osaka 573-1010, Japan \\ ${ }^{3}$ Lake Biwa Environmental Research Institute, 5-34 Yanagasaki, Otsu, Shiga 520-0022, Japan
}

\begin{abstract}
Nasty smell of tap water supplied from Lake Biwa caused a great trouble. Then many researches have been conducted from the point of view of water supply management or water quality in Japan. The matter of this bad smell was identified as 2-methylisoborneol (2-MIB) and the source organism of this bad odor was then reported as Phormidium tenue and later two different cultured strains were established. One of these strains shows green color, produce 2-MIB, and is marked PTG. The other shows brown color, does not produce 2-MIB and is marked PTB. However their nomenclatural description has not been done yet and, in fact, they have morphological characters of genus Pseudanabaena rather than Phormidium. Pseudanabaena species are also observed in Lake Kasumigaura. PS1306 produces 2-MIB and other strain PS1303 has no smell. This study focuses on morphological and genetical (16S rRNA) comparison of strains from both lakes. In addition, the ultrastructure of cells of PTB and PTG are demonstrated. On the basis of this comparison we propose description of two new planktic species producing 2-MIB: Pseudanabaena foetida NiIYAMA, TuJ et IcHISE sp. nov. and P. subfoetida NIIYAMA et TuJI sp. nov.
\end{abstract}

Key words: Lake Biwa, Lake Kasumigaura, 2-methylisoborneol (2-MIB), Phormidium tenue, Pseudanabaena foetida, Pseudanabaena subfoetida, Pseudanabaenaceae, PTB, PTG, 16S rRNA gene

\section{INTRODUCTION}

In 1969, nasty smell of tap water supplied from Lake Biwa (Fig. 1), which is the largest lake in Japan, caused a great trouble. The source organism of this trouble was investigated afterward and became known to be a thin filamentous cyanobacteria. This cyanobacteria was reported then as Phormidium tenue (Menegh.) Gomont and the cultured strains were established. The substance causing the musty odor was identified as 2-methylisoborneol (2-MIB) (YAGI 1983; YAMADA et al. 1985, 1986). Later, it was apparent that two kinds of cyanobacteria species were contained in the above mentioned cultured strains. One shows green color, produces $2-$ MIB and has musty odor, and is called PTG, the other shows brown color, does not produce 2-MIB and is called PTB.

PTG and PTB have morphological characteristics of genus Pseudanabaena as follows; trichomes are solitary or in small clusters, straight or slightly curved, with conspicuous constrictions at cross-walls, less than $2 \mu \mathrm{m}$ wide and without sheath; apical cells are not differentiated and without calyptra; cells are cy- lindrical, longer than wide. Although many researches about these strains had been conducted in Japan from the point of view of water supply management or water quality, nomenclatural description has not been done yet. The species name Phormidium tenue is still used for both strains and similar cyanobacteria producing 2MIB especially in the field of applied biology in Japan. In Japan, it is reported that several species and cultured strains of bloom-forming cyaobacterial algae, especially Microcystis and Dolichospermum (Anabaena) produce the toxin as microcystin, anatoxin or cylindrospermopsin (WATANABE et al. 1994). Although a red colonial Pseudanabaena rutilus-viridis from Canadian large lakes is indicated to have the ability to produce the toxin microcystin (KuING et al. 2012), no species of the family Pseudanabaenaceae is reported to produce the toxin in Japan. The matter of concern in Japan is water quality or smell of drinking water supplied from reservoirs and bad smell of fish and shellfish caused by thin filamentous algae, so called Phormidium tenue like species. The substances causing the musty odor are identified as 2-methylisoborneol (2-MIB) or geosmin (YAGI 1983), and troubles caused by the musty 
odor producing cyanobacteria are reported from several lakes, reservoirs or ponds in Japan (cf. MORII et al. 1982; Yamada et al. 1985, 1986; OiKawa et al. 2000; OiKaWA \& IsHibashi 2004), but there is almost no systematic study about the organisms causing the above mentioned troubles. Recently, the species names in Japan are even more confusing because several researchers observe the light-microscopic morphology of odor producing cyanobacteria and use species names quoted from the new systematics of Oscillatoriales (KOMÁREK $\&$ AnAgnostidis 2005) and others still use name Phormidium tenue. NGUYen et al. (2012) describe Annamia toxica gen. et sp. nov. based on the ultrastructural and phylogenetic study. This species is first identified and reported as Pseudanabaena cf. moniliformis (NGUYen et al. 2007). DvořÁK et al. (2015) point out the importance of consideration of cryptic diversity in cyanobacteria and describe a new monospecific genus Pinocchia with Pseudanabaena-like morphology using molecular, ecological and morphological data. Therefore systematic study being composed of detail morphological description, ecological observation and phylogenetic analysis is needed to clarify the Japanese species producing 2-MIB.

Then we began to analyze the morphology and 16S rRNA gene sequences of PTB and PTG strains. Comparison of the ultrastructure in cells, especially the arrangement of thylakoids in cells are so useful for taxonomic evaluations of cyanophyta (WHITTON 1972; ANAGNOSTIDIS \& KoMÁREK 1988; KOMÁREK \& ČÁSLAVSKÁ 1991; KomÁREK \& KAŠTOVSKÝ 2003;

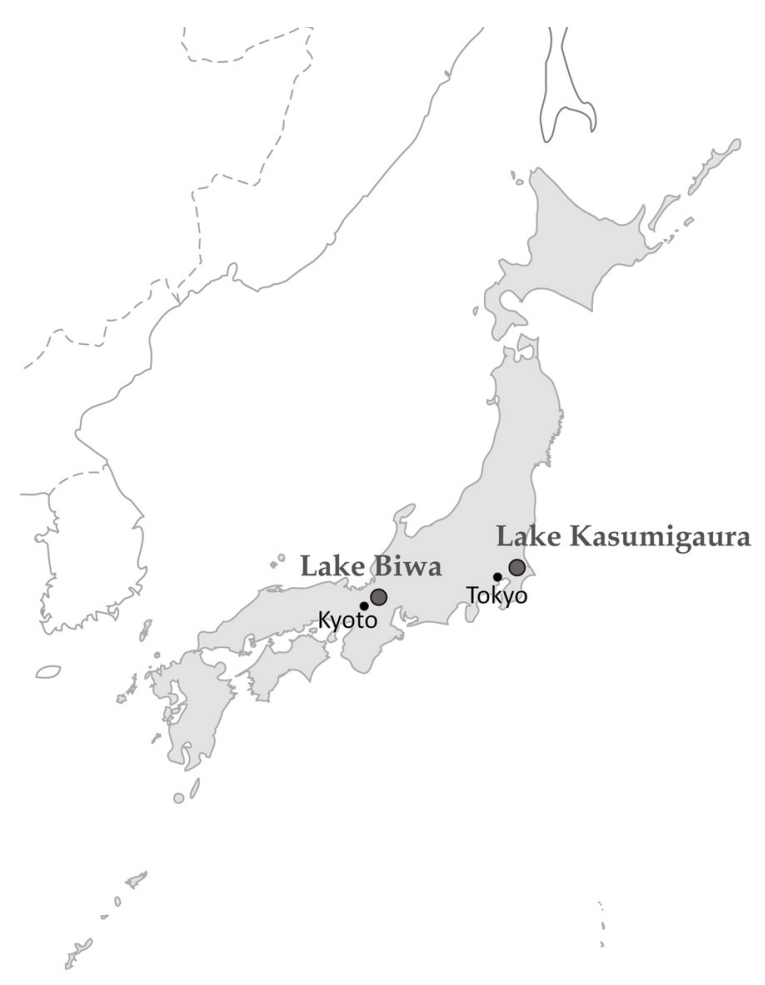

Fig. 1. Site map of Lake Biwa and Lake Kasumigaura in Japan.
KomÁREK \& ANAGNOSTIDIS 2005). Three main kinds of thylakoid arrangements correspond with three families in Oscillatoriales; parietal, radial and irregular arrangement of thylakoids are typical of Pseudanabaenaceae, Phormidiaceae and Oscillatoriaceae, respectively. Light and electron microscopic observations of PTB and PTG are conducted in this research to confirm their taxonomic position.

In the course of the study of PTB and PTG, we observed Pseudanabaena species almost throughout the year in Lake Kasumigaura (Fig. 1), which is the second largest lake in Japan. We could establish several Pseudanabaena strains from Lake Kasumigaura. Strains originated from Lake Kasumigaura resemble PTG and PTB in their morphology when they are observed under the light microscope of low magnification. One strain from Lake Kasumigaura produces 2MIB and has same extreme musty smell as PTG (TuJI et al. unpublished data).

This study focuses on comparison of the morphology and genetic characteristics of four cultured strains from both lakes. Moreover, morphological data of other nature and fixed materials and ultrastructure of PTB and PTG strains are demonstrated.

\section{Materials And Methods}

Cultured strains. The strains PTG and PTB were collected from Lake Biwa during the summer in 1985. The area of Lake Biwa is ca. $670 \mathrm{~km}^{2}$ and its maximum depth is $103.58 \mathrm{~m}$ and mean depth is $41.2 \mathrm{~m}$. The strain PS1303 and the strain PS1306 were collected in March and June, respectively, from Lake Kasumigaura in 2013. The area of Lake Kasumigaura is ca. $220 \mathrm{~km}^{2}$ and its maximum depth is $7.1 \mathrm{~m}$ and mean depth is $4.0 \mathrm{~m}$. Isolation was done by the pipette washing method under a binocular or agar plate method (TuJI \& NIIYAMA 2014) with d medium (modified WC medium: Tuлr 2000). 10 $\mathrm{ml}$ of culture medium contained in a test tube was used for maintenance of strains. CT medium (ICHIMURA \& WATANABE 1977) or M-11 medium (YAGI et al. 1979) was used for strains PTG and PTB, and modified C medium (IChIMURA \& Watanabe 1977, NiIyama et al. 2011) was used for strains originated from Lake Kasumigaura and PTG and PTB. The cultures were illuminated by cool-white fluorescent lamps, with photon flux density of ca. $20 \mu \mathrm{mol} \cdot \mathrm{m}^{-2} \cdot \mathrm{s}^{-1}$, a photoperiod of 8 hours light and 16 hours dark, and a temperature of $18{ }^{\circ} \mathrm{C}$ or $20^{\circ} \mathrm{C}$. Morphological observation was performed for these cultured strains under the light microscope (BH-2, Olympus Corporation, Tokyo, Japan). Microphotographs were taken with a Canon digital camera EOS Kiss X5 (Canon Inc., Tokyo, Japan). Fifty measurements were conducted for calculating the cell width and length of each strains. Cultured strains PTB and PTG are maintained in the Lake Biwa Environmental Research Institute, and strains PS1303 and PS1306 are maintained in the Department of Botany, National Museum of Nature and Science in Tsukuba, Japan. The specimens (TNS-AL in TNS) are kept in the herbarium of the Department of Botany, National Museum of Nature and Science (Table 1). To compare with the European strain, the morphology and 16S rRNA gene of cultured strain 
NIVA-CYA 276/6 originating from Sweden were also analyzed. Modified $\mathrm{C}$ medium and above mentioned illumination, temperature and photoperiod conditions were used for NIVA-CYA 276/6.

Fixed material. Photographs of trichomes of Pseudanabae$n a$ were taken, which were in a sample collected from Lake Biwa in 1980 and fixed with formaldehyde. The trichomes in this sample, called Biwa1980 in this paper, had been identified as Phromidium tenue green-type with bad smell. The cell width and length of Biwa1980 were measured for comparing with those of PTG.

Ultrastructure (Transmission Electron Microscopy). The laboratory-cultured cyanobacterial cells were harvested by centrifugation (PTG: $12,000 \mathrm{rpm}, 10 \mathrm{~min}, 15^{\circ} \mathrm{C}$. PTB: 3,000 $\left.\mathrm{rpm}, 10 \mathrm{~min}, 15^{\circ} \mathrm{C}\right)$. After washing with a cacodylate buffer $0.1 \mathrm{M}(7.4 \mathrm{pH})$, the pelleted cells were prefixed with $2.5 \%$ glutaraldehyde (TAAB Laboratories Equipment Ltd) in the cacodylate buffer at room temperature for $30 \mathrm{~min}$. After washing with the buffer, the material was postfixed with $1 \%$ osmium tetroxide (TAAB Laboratories Equipment Ltd) in the buffer for $30 \mathrm{~min}$ at room temperature. Fixed cells were rinsed again and dehydrated by ethanol and embedded in Epon 812 resin (TAAB Laboratories Equipment Ltd). The samples were sectioned using an ultramicrotome (Reichert-Nissei), and mounted on EM grids. Sections $(80 \mathrm{~nm})$ for the ultrastructural analyses were stained for $15 \mathrm{~min}$ with uranyl acetate followed by $5 \mathrm{~min}$ in lead citrate. Transmission electron microscope (TEM) images were acquired by using JEOL JEM 1400 TEM operating at $80 \mathrm{kV}$ accelerating voltage.

Genomic DNA extraction, PCR amplification and sequencing. $1.5 \mathrm{ml}$ of fresh culture material was centrifuged at $10,000 \mathrm{rpm}$ for $5 \mathrm{~min}$ at room temperature. The supernatant was removed and the cell pellets were kept in freezer at 4 ${ }^{\circ} \mathrm{C}$ until extraction. Total genomic DNA was extracted using the extraction kit (PP-207, Jena bioscience) following the instructions of the manufacturer. 16S rRNA, 16S-23S internal transcribed spacer (ITS) and partial 23S rRNA gene were amplified by using the two primers sets, set A: universal primer 27f (5'-AGA GTT TGA TCM TGG CTC AG-3' : LANE 1991) and Pseudanabaena specific primer designed in this study, PS16s600r (5'-TCC TGC CCC TAT CTC TCT C-3': designed in this study) and set B: Pseudanabaena specific primer, PS16s440f (5'-ACC TCT TTT GTT AGG GAA GAT AAT G-3': designed in this study) and cyano-specifric primer, pitsE-cyanR (5'-CTC TGT GTG CCA AGG TAT C-3' : ERnst et al. 2003). PCR was performed on a Thermal Cycler (iCycler, BioRad), using 10 $\mu 1$ KAPA plant PCR buffer, $0.1 \mu 1$ KAPA3G Plant DNA polymerase, $0.04 \mu 1 \mathrm{KAPA}$ Plant PCR Enhancer (KAPA Biosystems), 7.46 $\mu 1$ sterile deionized water, $0.7 \mu 1$ each of $10 \mathrm{pM}$ concentration of forward and reverse primers, and $1 \mu \mathrm{LNA}$ template. The temperature cycling program was used the following conditions: $95{ }^{\circ} \mathrm{C}$ for $4 \mathrm{~min}$; 40 cycles of $95^{\circ} \mathrm{C}$ for $20 \mathrm{sec}, 54{ }^{\circ} \mathrm{C}$ for $15 \mathrm{sec}, 72$ ${ }^{\circ} \mathrm{C}$ for $40 \mathrm{sec}$; the final elongation step was $72{ }^{\circ} \mathrm{C}$ for $7 \mathrm{~min}$. The concentration of the amplified products was verified on a $1 \%$ agarose gel. Direct sequencing of PCR products, with primers 27f and PS16s600r for set A, and PS16s440f, F3L (5'-GTC CCG CAA CGA GCG CAA C-3') and pitsE-cyanR for set $\mathrm{B}$, were undertaken using Big Dye Terminator Chemistry and an ABI 3130xl Genetic Analyzer (Applied Biosystems, Foster City, CA). The Basic Local Alignment Search Tool (BLAST) of the National Center for Biotechnology Information (NCBI) was utilized for locating strains/ sequences similar to our species. We used 5 new sequences obtained in this study, and 18 sequences from NCBI after performing BLAST. The short sequences from NCBI, were delimited from our analysis. Phylogenetic and molecular evolutionary analyses of the obtained sequences were conducted using the MEGA 5 computer program (TAMURA et al. 2011). Alignments were computed using MUSCLE in MEGA 5, and checked manually. A maximum likelihood (ML) and Neighbour-joining (NJ) trees were calculated using MEGA software with the best fit model determined by Akaike Information Criterion (AIC) corrected scores, and the substitution nucleotide matrix parameters were calculated by the software. A sequence for Pseudanabaena sp. 1a-03 (FR798944.1) was used for an out-group. One thousand bootstrap replicates were performed for NJ and ML analysis. The DNA sequences obtained in this study have been deposited in the DDBJ under the GenBank accession numbers as follows (see Table 1); PTB: LC016774, PTG: LC016773, PS1303: LC016775, PS1306: LC016779, and NIVA-CYA276/6: LC016776.

Secondary structure models of ITS regions. The putative secondary structures of the $16 \mathrm{~S}-23 \mathrm{~S}$ rRNA ITS region were predicted with the Mfold Web server using version 2.3 (ZuKER 2003), with temperature set at $20^{\circ} \mathrm{C}$, but all other settings at default followed by Siegesmund et al. (2008).

\section{Results}

The parietal arrangement of thylakoids in cells was observed for both PTB (Fig. 2) and PTG (Fig. 3). Because the parietal pattern of thylakoid arrangement is characteristic in the family Pseudanabaenaceae, PTB and PTG are considered to be a member of Pseudanabaenaceae, thus the name Phormidium tenue is wrong. The morphology of trichomes and cells of Japanese strains PTG, PTB, PS1303 and PS1306 and Swedish one NIVA-CYA $276 / 6$ is seemingly similar under the light microscope of low magnification (Figs. 4, 6, $8,10,12)$, but the cell size measured under the light microscope of high magnification and other characters such as trichome color, odor, etc. of each strain are different as shown in Tables 1 and 2.

Then differences of cell width and cell length among PTG, PS1306 and Biwa1980 were evaluated using analysis of variance (ANOVA). As the calculated $F$ values are higher than the $\mathrm{F}^{2}{ }_{111}(0.01)=4.802$, there is a significant difference among PTG, PS1306 and Biwa1980. The differences of cell width and cell length between PTB and PS1303 were evaluated by ttest. There are significant differences between the cell width and the cell length between PTB and PS1303 $(\mathrm{p}<0.001)$.

The trichome color of PTB is brownish green but those of PTG, PS1303, PS1306 and NIVA-CYA 276/6 are bright blue-green (Table 2). Trichomes of every strains have no sheath at the beginning of cultivation. Trichomes of PTG, PS1306 and NIVA-CYA 276/6 are growing separately but trichomes of PTB and 
PS1303 are sticky and sometimes grow close together and form small colonies (Figs. 4, 8). Only the old trichomes of PS1303 have very thin sheath and they stick together to form a thin membranous colony, but other cultured strains have no sheath even in the late growing stage.

The cell color of PTB is pale blue-green to olive green. The cell color of PTG, PS1303, PS1306 and NIVA-CYA $276 / 6$ is bright blue-green. Cells of PTB and PTG are long cylindrical and clearly longer than wide. The mean value of L/W of PTB and PTG are larger than other strains (Table 1). The cells of PS1303 are short to long cylindrical, and those of PS1306 and

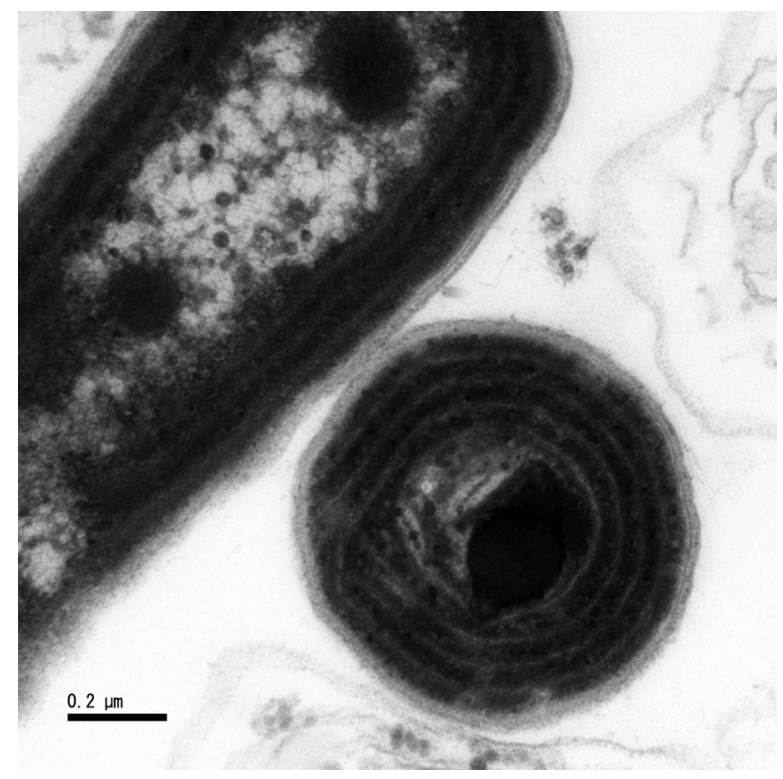

Fig. 2. TEM photo of cells of PTB, Pseudanabaena limnetica. Scale bar $0.2 \mu \mathrm{m}$.

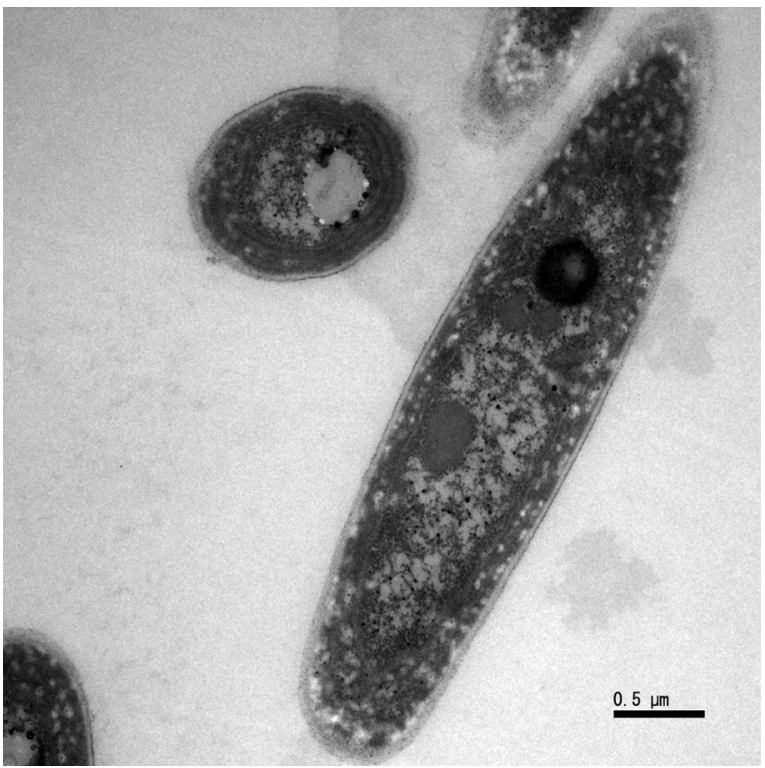

Fig. 3. TEM photo of cells of PTG, Pseudanabaena. foetida sp. nov Scale bar $0.5 \mu \mathrm{m}$.
NIVA-CYA 276/6 are nearly isodiametric to longer than width and with rounded ends. The ends of cells of PTG, PS1306 and NIVA-CYA 276/6 are rounded and there is a clear aerotope at the both ends of each cell of these three strains. The aerotopes of PTG, PS1306 and NIVA-CYA 276/6 are colorless and transparent, and their trichomes are intensely constricted at the crosswalls, then each cell seems to be connected with bright shining papillae and trichomes seem to have small conical protrusions at the apical cells when observed under the light microscope of lower magnification. PTB and PS1303 have an apical small aerotope at the both ends of each cell and the cells of their trichomes also seem to be connected with small bright papillae under the light microscope of lower magnification. Cell content of PS1306, NIVA-CYA 276/6 and sometimes PTG are differentiated between centroplasmic and chromatoplasmic regions. There are several small granules in the cells of PS1306. Cell content of PTB and PS1303 seems to be almost homogeneous.

Phylogenetic analysis of our four strains (PTB, PTG, PS1303, PS1306), NIVA-CYA 276/6 and related 18 taxa, is shown in Fig. 16. PTB and PS1303 are included in the same cluster with high bootstrap values (96 for NJ and 92 for ML) and cluster with Oscillatoria limnetica (synonym of Pseudanabaena limnetica). PTG and PS1306 are included in another cluster with high bootstrap values (92 for NJ and 93 for ML). PTG and PS1306 differ 12 base positions ( $0.8 \%$ of $1462 \mathrm{bp}$ ) in $16 \mathrm{~S}$ rRNA gene region and 26 base positions $(4.9 \%$ of 534bp) excluding $45 \mathrm{bp}$ gaps in ITS region. The difference of the secondary structures of the 16S-23S rRNA ITS region of PTG and PS1306 was also found (Figures S1 and S2), and it suggests the species level difference for both strains.

As a result of phylogenetic and morphological analysis, PTB and PS1303 are concluded to be Pseudanabaena limnetica. On the other hand, both PTG and PS1306 have very unique character producing 2-MIB which has strong musty odor but their trichome width, cell morphology and phylogenetic result are different from each other, so we propose two new species, Pseudanabaena foetida NiIYAMA, Tus et IcHISE for PTG and Pseudanabaena subfoetida NiIYAma et Tuj for PS1306 as follows.

Pseudanabaena foetida Niryama, Tuji et ICHISE sp. nov. (Figs 6, 7)

Description: Trichomes solitary, straight or slightly curved, bright blue-green colored, with conspicuous constrictions at cross-walls, $1.0-1.7(-2.2) \mu \mathrm{m}$ wide, without mucilage or sheath, not attenuated nor differentiated at the ends, without calyptra, infrequently move. Cells long cylindrical with rounded ends, bright blue-green, longer than wide, 3.4-11.0 $\mu \mathrm{m}$ long, ratio of width to length ca.1.7-8.5, with aerotopes at both ends of cells, differentiated in centro- and chromatoplasmic regions. Cell division perpendicular to 
the longitudinal axis of a trichome. Trichomes separate between two neighboring cells or by fragmentation without necridic cells. Hormogonia trembling. Heterocytes are not known. Thallus has the extreme musty odor that comes from 2-methylisoborneol.

Holotype: A formalin fixed specimen, TNS-AL57781 in TNS (Department of Botany, National Museum of Nature and Science), from cultured strain PTG. Type strain: PTG maintained in the Lake Biwa Environmental Research Institute, Japan.

Iconotype: Fig. 14.

Type locality: Lake Biwa, Shiga Pref., Japan.

Habitat: Plankton in lakes.

Etymology: the epithet name foetida reflects the bad smelling of this species.

\section{Pseudanabaena subfoetida Niryama et Tuji sp. nov.} (Figs 10, 11)

Description: Trichomes solitary, straight, bright bluegreen colored, with conspicuous constrictions at crosswalls, 2.1-2.9 $\mu \mathrm{m}$ wide, without mucilage or sheath, not attenuated nor differentiated at the ends, without calyptra, infrequently move. Cells isodiametric to longer than wide with rounded ends, bright blue-green, 2.5-8.5 $\mu \mathrm{m}$ long, ratio of width to length ca.0.9-4.0, with aerotopes at both ends of cells, sometimes with several small granules, clearly differentiated in centroand chromatoplasmic regions. Cell division perpendicular to the longitudinal axis of a trichome. Trichomes separate between two neighboring cells or by fragmentation without necridic cells. Hormogonia trembling. Heterocytes are not known. Thallus has the extreme musty odor that comes from 2-methylisoborneol as same as Pseudanabaena foetida.

Holotype: A formalin fixed specimen, TNS-AL-58650 in TNS (Department of Botany, National Museum of Nature and Science), from cultured strain PS1306.

Type strain: PS1306 maintained in the Department of Botany, National Museum of Nature and Science, Japan.

Iconotype: Fig. 15.

Type locality: Lake Kasumigaura, Ibaraki Pref., Japan. Habitat: Plankton in lakes.

Etymology: the epithet name subfoetida reflects the same bad smelling as and different cell morphology from Pseudanabaena foetida.

\section{Discussion}

The cultured strains PTB and PTG have been cultivated for about 30 years, so their morphology may have been changed, for example their trichome width may have been thinner than the initial stage. Unfortunately, we have no data of trichome width or cell size of PTB and PTG at the beginning of their cultivation. As far as the photographs and descriptions of so called musty odor producing strains established at the same period of PTG (Moril et al. 1982; YAMADA et al. 1986) are compare to PTG, trichome or cell width of those strains are 1.4 to $1.8 \mu \mathrm{m}$ and somewhat wider than those of PTG. The cell width of Biwa1980 is discontinuously wider than those of PTG (Table 1, Fig. 17). Takemoto et al. (2012) point out that PTB has thin mucilaginous sheath but PTG has not any sheath when observed under the low temperature/low vacuum SEM, and that the cell width of PTG is $1.0-1.7 \mu \mathrm{m}$ (mean value $1.35 \mu \mathrm{m}$ ) and is 1.3 times larger than that of PTB. It is unclear that the trichome width of PTG have become smaller or not after the 30 years cultivation, but PTG has kept producing 2-MIB for 30 years.

YAMADA et al. (1985) report that the optimum temperature, $\mathrm{pH}$ and light intensity for growth and 2MIB production of the strain are $20-25^{\circ} \mathrm{C}, 8-9$ and 1000-2000 lux, respectively, and its production rate of 2-MIB is directly proportional to its growth rate. IwASE \& ABE (2010) also report that 2-MIB synthesis increases as cells grow in strain NIES-512. IWASE and $\mathrm{ABE}$ (2010) also point out that cells grow between $10-35^{\circ} \mathrm{C}$ and the concentration of 2-MIB is highest at $25^{\circ} \mathrm{C}$ but $2-\mathrm{MIB}$ is significantly synthesized even at $10{ }^{\circ} \mathrm{C}$ and furthermore the concentration of 2-MIB is considerably high at exponential growth phase when cells are incubated under phosphate- and light-limiting conditions. Therefore the production of $2-\mathrm{MIB}$ is considered to be one of the taxonomic characters for genus Pseudanabaena.

There are aerotopes at both ends of cells of Pseudanabaena foetida and P. subfoetida. Then the apical part of the terminal cells and the cross-walls of each cell seem to shine under the light microscope. The shape of aerotopes of $P$. foetida and $P$. subfoetida are helmet-shape to hemispherical as those of $P$. galeata BöCHER (BöCHER 1949). Cell content of P. subfoetida sometimes has several small granules and the cell content of trichomes seems to be separated with centroand chromatoplasmic regions as P. biceps (BöcHER 1946). The morphology of $P$. foetida (Figs. 6, 7, 14) looks like $P$. galeata and that of $P$. subfoetida (Figs. $10,11,15)$ looks like $P$. biceps, although the apical cells of $P$. subfoetida are rounded and not roundedpointed at the ends. $P$. biceps and $P$. galeata are benthic in small and shallow brackish lakes with muddy bottom (BöCHER 1946, 1949) or P. galeata is epiphytic or endogloeic and solitary trichomes rarely secondary in plankton (KomÁReK \& ANAgnostidis 2005). $P$. foetida and $P$. subfoetida are planktic in relatively large freshwater lakes. P. biceps shows vivacious creeping or gliding movement (Böcher 1946) and P. galeata also shows movement. On the other hand, P. foetida and $P$. subfoetida rarely show motility, and the trichomes infrequently slowly move forwards. Shorter trichomes consisting of two to several cells (hormogonia) sometimes tremble or move forwards faster than the longer ones but they do not glide or creep as species of 

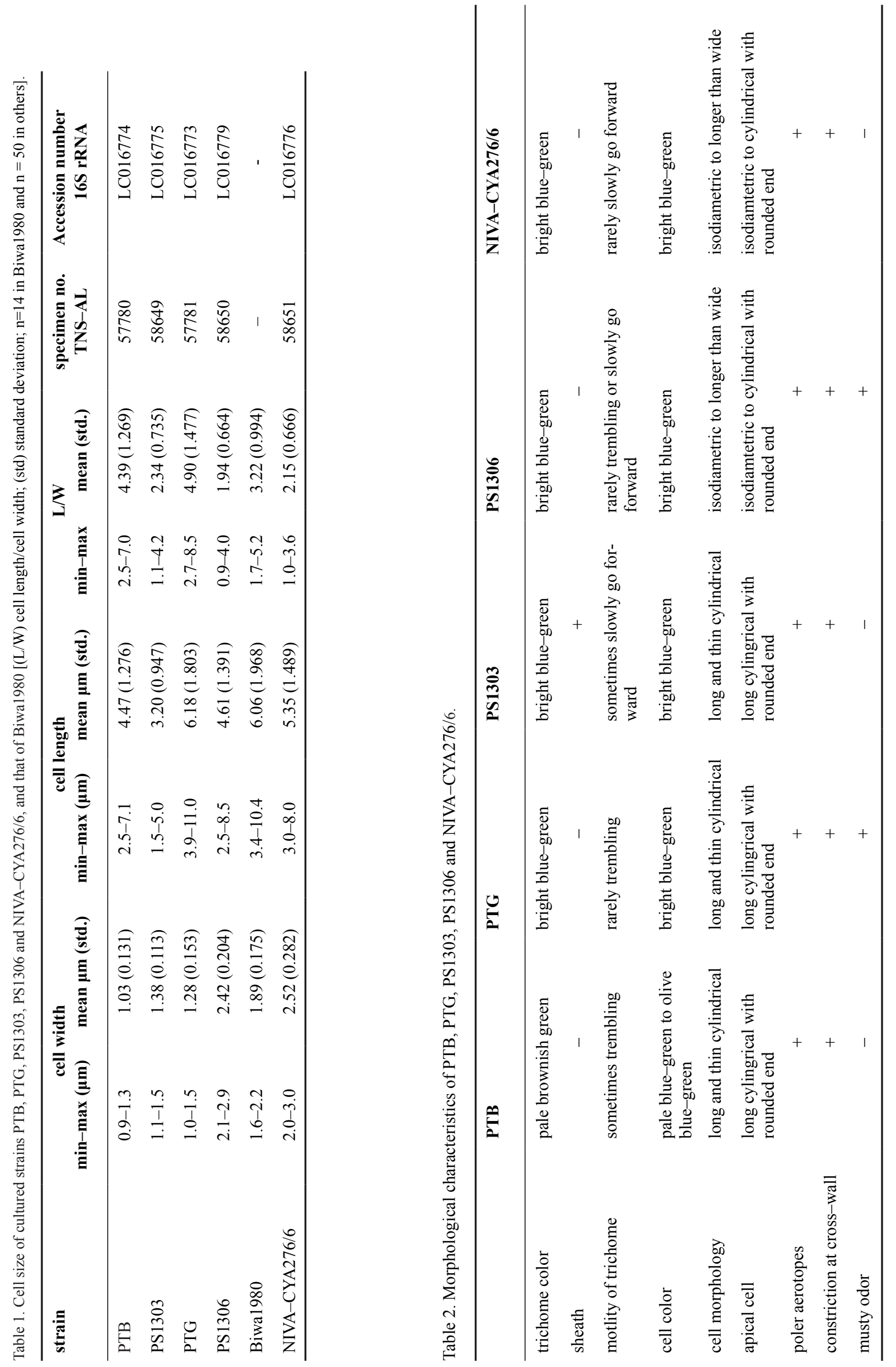


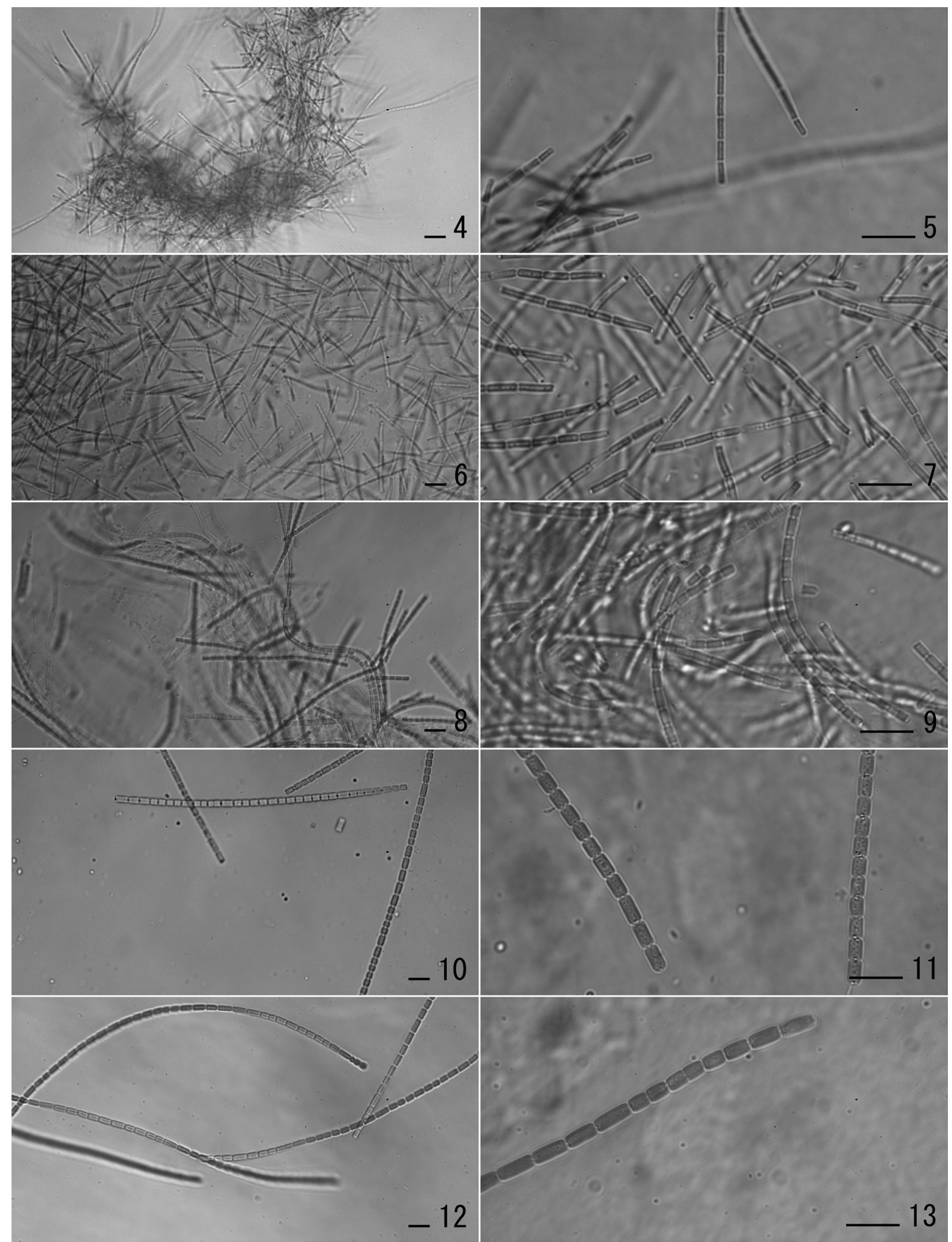

Figs. 4-13. Photos of five Pseudanabaena strains, PTB, PTG, PS1303, PS1306 and NIVA-CYA 276/6: (4, 5) PTB, Pseudanabaena limnetica; $(6,7)$ PTG, . foetida sp. nov.; (8, 9) PS1303, Pseudanabaena limnetica; $(10,11)$ PS1306, P. subfoetida sp nov.; $(12,13)$ NIVA-CYA $276 / 6$. Scale bars $10 \mu \mathrm{m}$. 


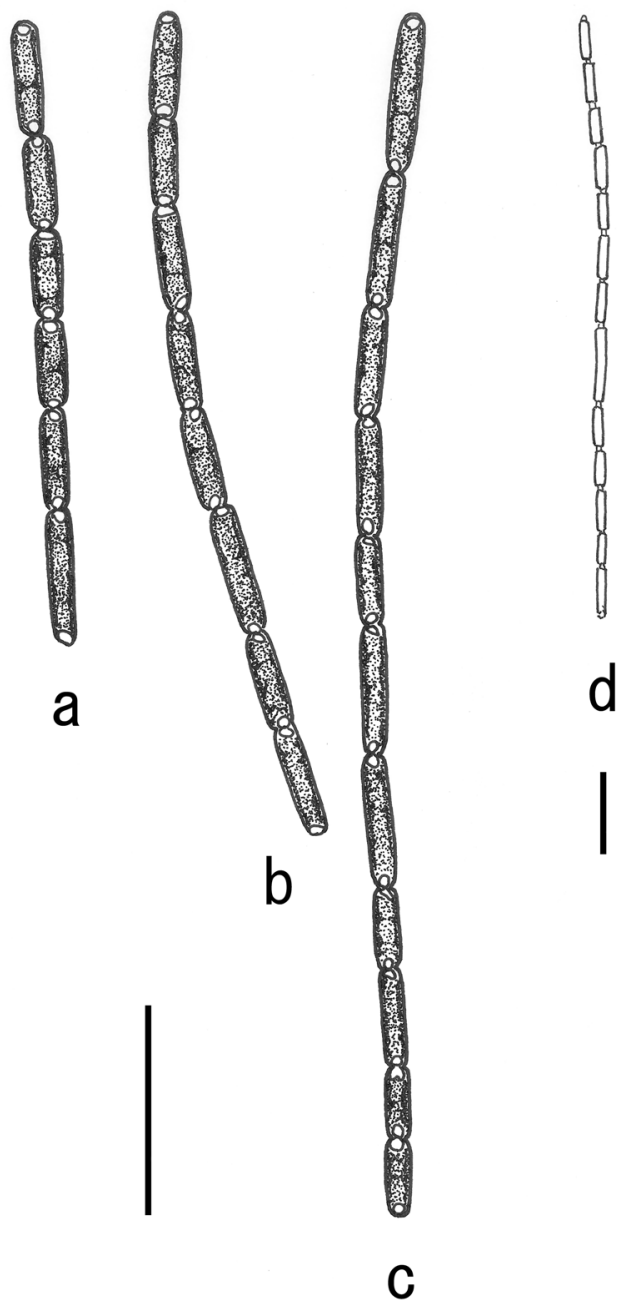

Fig. 14. Drawings of $P$. foetida sp. nov. Scale bars $10 \mu \mathrm{m}$.

Geitlerinema or Phormidium. And $P$. foetida and $P$. subfoetida live in solitary and do not form fine mats nor cluster in small groups. These characteristics are also different from those of $P$. galeata or P. biceps and other members of subgen. Illyonema species (KOMÁREK \& Anagnostidis 2005). Böcher (1946, 1949) points out that $P$. biceps and $P$. galeata live on the mud which smells strongly of sulphureted hydrogen but he does not describe the smell of themselves.

From the result of our phylogenetic analysis, $P$. foetida and $P$. subfoetida are in a different clade of $P$. galeata and seem to be closely related to Pseudanabaena sp. dph15 and NIVA-CYA 276/6 (Fig. 16). The Chinese strain collected from Lake Dongqian, Pseudanabaena sp. dph15, is in the same clade of $P$. foeteida and P. subfoetida (Fig. 16) and reported to have 2-MIB synthesis associated operon (HQ830028.1). NIVA-CYA $276 / 6$ seems to be misidentified as Pseudanabaena limnetica, as it is morphologically and genetically different from $P$. limnetica (Figs. 12, 13 and 16). Although the morphology of NIVA-CYA 276/6 is very similar to that of $P$. subfoetida, NIVA-CYA $276 / 6$ has no smell and is considered to be a distinct species

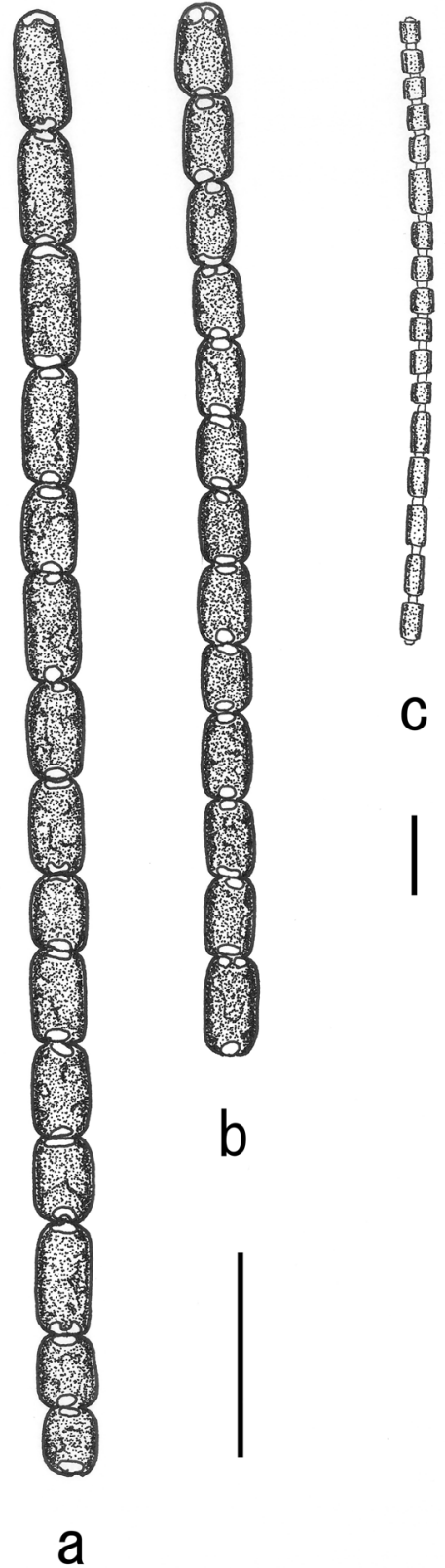

Fig. 15. Drawings of $P$. subfoetida sp. nov. Scale bars $10 \mu \mathrm{m}$.

from $P$. foetida and $P$. subfoetida.

ACKNOWLedGements

We would like to thank Dr. J. Komárek for answering our questions, Dr. Otakar Strunecký for discussing the phylogenetic position of our strains, and Dr. Athena Economou-Amilli for giving us an advice on the specific name. We thank to Dr. N. Takamura, Dr. S. Matsuzaki and Ms. M. Nakagawa, Center for Environmental Biology and Ecosystem Studies, National Institute for Environmental Studies, Japan. We also thank to Mr. A. Saito, Institute of Biomedical Science Central Research Center, Kansai Medical University, and colleagues of Lake Biwa Environmental Research Institute. A part of this study was supported by a Grant-in-aid for Plant Research (The New Technology Development Foundation, Japan), JSPS KAKENHI no. 24510039 (K. Takemoto). 


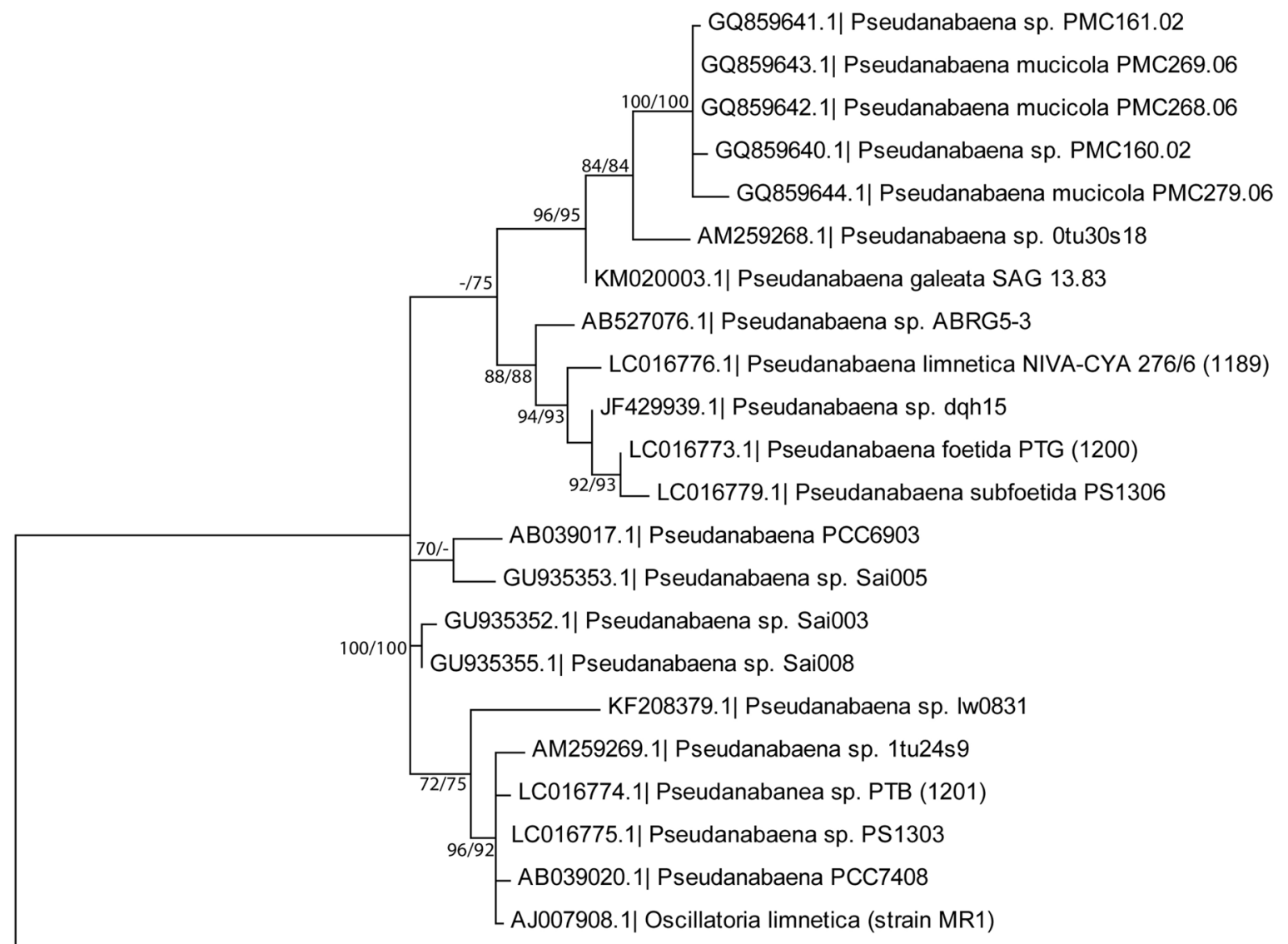

FR798944.1| Pseudanabaena sp. 1a-03

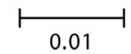

Fig. 16. Phylogenetic position of Pseudanabaena foetida, P. subfoetida and related taxa determined by Maximum Likelihood (ML) method using $16 \mathrm{~S}$ rRNA gene. Accession numbers are followed by taxonomic names. Numbers at branches indicate NJ (Neighbor Joining)/ML bootstrap support values (only values higher than 60 are shown).

\section{REFERENCES}

Anagnostidis, K. \& KomÁReK, J. (1988): Modern approach to the classification system of cyanophytes 3 - Oscillatoriales. - Algological Studies 50-53: 327-472.

Böcher, T. W. (1946): Pseudanabaena biceps, a new sapropelic species from bottom mud. - Botaniska Notiser 2: $281-284$.

BöCHER, T. W. (1949): Studies on the sapropelic flora of the lake Flyndersø with special reference to the Oscillatoriaceae. - Kgl. danske videnskabernes selskab, Biologiske Meddelelser 21: 1-46.

Dvořák, P.; Cronberg, G.; Moestrup, Ø. \& Daugbjerg, N. (2015): A new tropical cyanobacterium Pinocchia polymorpha gen. et $\mathrm{sp}$. nov. derived from the genus Pseudanabaena. - Fottea 15: 113-120.

Ernst, A.; Becker, S.; Wollenzien, U. \& Postius, C. (2003): Ecosystem-dependent adaptive radiations of picocyanobacteria inferred from 16S rRNA and ITS-1 sequence analysis. - Microbiol SGM 149: 217-228.

Ichimura, T. \& WatanABe, M. M. (1977): An axenic clone of Microcystis aeruginosa Kütz . emend. Elenkin from Lake Kasumigaura. - Bull. Jpn. Soc. Phycol. 25: 177-181.

IWASE, S. \& ABe, T. (2010): Identification and change in con- centration of musty-odor compounds during growth in blue-green algae. - J. School of Marine Science and Technology, Tokai Univ. 8: 27-33.

Kling, H.J.; Laughinghouse IV, H.D.; Šmarda, J.; KomáreK, J.; Acreman, J.; Bruun, K.; Watson, S.B. \& Chen, F. (2012): A new red colonial Pseudanabaena (Cyanoprokaryota, Oscillatoriales) from North American large lakes. - Fottea 12: 327-339.

KomÁreK, J. \& ANAgnostidis, K. (2005): Cyanoprokaryota. 2. Teil: Oscillatoriales. - In: BÜDEL, B.; GÄrdNER, G.; Krienitz, L. \& Schagerl. M. (eds): Süswasserflora von Mitteleuropa, vol. 19/2. - 759 pp., Elsevier, München.

KOMÁREK, J. \& ČÁSLAVSKÁ , J. (1991): Thylakoid patterns in oscillatorialean cyanophytes. - Algological Studies 64: 267-270.

KomÁReK, J. \& KAŠTOVSKÝ, J. (2003): Coincidences of structural and molecular characters in evolutionary lines of cyanobacteria. - Algological Studies 109: 305325.

LANe, D.J. (1991): 16S/23S rRNA sequencing. - In: STACKeBRANDT, E. \& Goodfellow, M. (eds): Nucleic acid techniques in bacterial systematics. - pp. 115-147, John Wiley \& Sons, New York, NY.

MoriI, H.; Kasama, K. \& Zentani, B. (1982): Musty odor- 


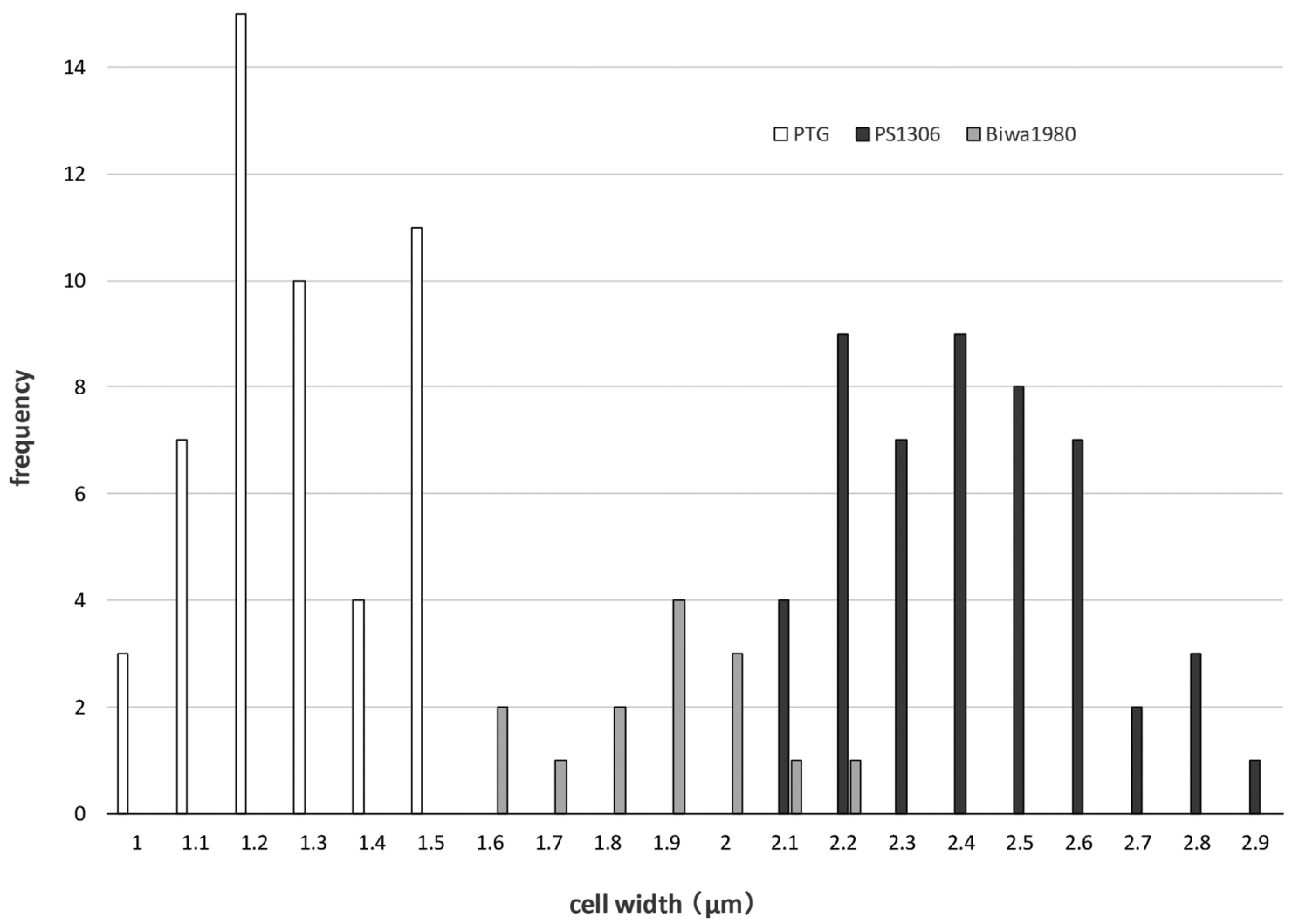

Fig. 17. Comparison of cell width distribution of cultured strains PTG, Biwa1980 and PS1306.

production by the cyanobacteria Pseudanabaena spp. isolated from reservoirs of water supply in Kure City. - Bull. Fac. Fish. Nagasaki Univ. 52: 47-54 (in Japanese with English abstract).

Nguyen, T.T.L.; Cronberg, G.; Larsen, J. \& Moestrup, Ø. (2007): Planktic cyanobacteria from freshwater localities in Thuathien- Hue province, Vietnam. I. Taxonomy and distribution. - Nova Hedwigia 85: 1-34.

Nguyen, T.T.L.; Cronberg, G.; Moestrup, Ø. \& Daugbjerg, N. (2015): Annamia toxica gen. et sp. nov. (Cyanobacteria), a freshwater cyanobacterium from Vietnam that produces micocystins: ultrastructure, toxicity and molecular phylogenetics. - Phycologia 52: 25-36.

Niryama, Y.; Tuj,, A. \& TsujImura, S. (2011): Umezakia natans M.Watan. does not belong to Stigonemataceae but Nostocaceae. - Fottea 11: 163-169.

Oikawa, E.; Ishibashi, Y.; Abe, T. \& Umetsu, H. (2000): Phylogenetic classification of musty odor and/or toxic compounds producing cyanobacteria. - Environmental Engineering Research 37: 183-191 (in Japanese with English abstract).

Oikawa, E. \& Ishibashi, Y. (2004): Species specificity of musty odor producing Phormidium tenue in Lake Kamafusa. - Water Science and Technology 49:4146.

Siegesmund, M.; Johansen, J.R.; Karsten, U. \& Friedl, T. (2008): Coleofasciculus gen. nov. (Cyanobacteria): morphological and molecular criteria for revision of the genus Microcoleus Gomont. - J. Phycol. 44: $1572-1585$

Takemoto, K; Yамамото, A.; Mizuta, G.; Ichise, S.; YoSHimura, M.; Namba, H. \& Kinara, H. (2012): Intracellular microstructural observation of musty odor producing filamentous cyanobacteria, Phormidium tenue, comparative observation using soft $\mathrm{X}$-ray microscope, transmission electron microscope, and low temperature/ low vacuum scanning electron microscope. - Jpn. J. of Water Treatment Biology 48: 157-163 (in Japanese with English abstract).

Tamura, K.; Dudley, J.; Nei, M. \& Kumar, S. (2007): MEGA4: Molecular evolutionary Genetics Analysis (MEGA) software version 4.0. - Mol. Biol. Evol. 24: 1596-1599.

Tuл, A. (2000): The effect of irradiance on the growth of different forms of freshwater diatoms: Implications for succession of attached diatom communities. - J. Phycol. 36: 659-661.

Tuin, A. \& NiIYAma, Y. (2014): Freshwater diatom flora in the Imperial Palace, Tokyo (2010-2013). - Mem. Natl. Mus. Nat. Sci., Tokyo 49: 75-88.

Watanabe, M.F., Harada, K. \& Fujiki, H. (eds) (1994): Waterbloom of blue-green algae and their toxins. -257 pp., University of Tokyo Press. Tokyo (in Japanese).

Whitton, B.A. (1972): Fine structure and taxonomy in the blue-green algae. - In: DesiKachary, T.V. (ed.): Taxonomy and biology of blue-green algae. - pp.1826, Madras. 
YAGI, M. (1983): Odor produced by blue green algae. - Eisei Kagaku 29:16-22 (in Japanese with English abstract).

YAGI, O.; OKadA, M. \& SUdO, R. (1979): Cultivation of Microcystis and red-tide-organisms. - Res. Rep. Natl. Insti. Environ. Stud. 6: 223-223 (in Japanese with English abstract).

Yamada, N.; Aoyama, K.; Yamada, M. \& Hamamura, N. (1985): Studied on earthy-musty odor in natural water (1). Growth characteristics and 2-methylisoborneol production of Phormidium tenue. - Research in Pollution of Water Supplies 8: 515-521 (in Japanese with English abstract).

Yamada, N.; Aoyama, K.; Yamada, M. \& Hamamura, N. (1986): Studied on earthy-musty odor in natural water (3). Isolation of bacteria-free Phormidium tenue and the effect of associated bacteria on the growth of axenic P. tenue. - Research in Pollution of Water Supplies 9: 379-385 (in Japanese with English abstract).

ZuKER, M. (2003): Mfold web server for nucleic acid folding and hybridization prediction. Nucleic Acids Res. 31: 3406-15.

Supplementary material

the following supplementary material is available for this article:

Fig. S1. Secondary structure of the 16S-23S rRNA ITS region of P. foetida (PTG).

Fig. S2. Secondary structure of the $16 \mathrm{~S}-23 \mathrm{~S}$ rRNA ITS region of P. subfoetida (PS1306).

This material is available as part of the online article (http://fottea.czechphycology.cz/contents)

(C) Czech Phycological Society (2016)

Received May 28, 2014

Accepted September 23, 2015 